\title{
Effect of Protected Calcium Salts of Fatty Acid-Amino Acid on Growth Rate of Young Ongole Crossbred Bulls
}

\author{
R. Antari ${ }^{1}$, Mariyono ${ }^{1}$, Y.N. Anggraeny ${ }^{1}$, N.H. Krishna ${ }^{1}$, A.S. Putri ${ }^{1}$, M.F. Ulum², E. Wina ${ }^{3}$
}

10.18805/IJAR.BF-1429

\begin{abstract}
Background: Protected calcium salts-fatty acid-amino acid supplement contains high-density of energy that can be used as cattle feed. This study aimed to test the efficacy of the supplements in the growth rate of young Ongole crossbred bulls.

Methods: Thirty Ongole crossbred bulls $(345 \pm 14 \mathrm{~kg}$; live weight $\pm \mathrm{SEm})$ were ranked and blocked based on liveweight and randomly allotted to one of three supplement levels (A: null $0 \mathrm{~g} / \mathrm{kg} ; \mathrm{B}: 0.3 \mathrm{~g} / \mathrm{kg}$ and C: $0.6 \mathrm{~g} / \mathrm{kg} \mathrm{LWs}$ ) and 10 replicates. All bulls were offered elephant grass and a concentrate diet containing $12 \%$ crude protein and $65 \%$ of total digestible nutrients. The parameters were liveweight gain, hip height gain, body condition score, feed conversion ratio, plasma fat and glucose concentrations, back fat and muscle depth.

Result: There was no significant difference in feed intake among treatment groups $(P>0.05)$. All bulls ate around $11 \mathrm{~kg} / \mathrm{d}$ on a $\mathrm{DM}$ basis, equal to around $2.8 \% \mathrm{LW}$. Bulls in $\mathrm{C}$ group were heavier and gained more weight $(P<0.05)$ and required less feed/kg LWG. The depths of backfat and muscle depth were no differences between treatments $(P>0.05)$. The inclusion of $0.6 \mathrm{~g} / \mathrm{kg} \mathrm{LW}$ of the supplement improve the growth rate of young Ongole crossbred bulls.
\end{abstract}

Key words: Amino acid, Bull, Calcium salts, Growth rate, Ongole.

\section{INTRODUCTION}

The common feeds used in tropical countries are usually from agricultural byproducts, with low nutritive quality characterized by low digestible nutrients, crude protein, soluble sugar and starch contents, while having high biomass and fiber content (Leng, 1990). The seasonal changes are also an issue in providing feed. In the dry season, the grass grows very poorly, resulting in low productive performance of ruminants (Fernandes et al. 2020). Providing supplements is an option to improve the nutritional content for cattle fed on low-quality crop residues. Studies reported that concentrate diet supplementation improved productive performance of cattle. Heifers supplemented with concentrate diet increased the liveweight gain (Carvalho et al. 2017) and the supplement also maintained the cow performance (Mediksa et al. 2021; Gekara et al. 2001). Despite the positive effect of concentrate diet supplementation, it is costly for most farmers in Indonesia.

Palm fatty acid distillate (PFAD) containing high densed energy (fat), accounting for $82 \%$ (Indarto et al. 2020) and it can be used as an energy supplement (Wina and Susana, 2013). However, high content of fat in the feed can be harmful for rumen microorganisms, therefore the fat should be protected. The calcium salts of fatty acid are protected lipid that is made from PFAD as the main ingredient that is a by-product of the crude palm oil refinery. The supplement is made through a process of saponification in a heating process (Strohmaier et al. 2003). The calcium salts of fatty acid are commonly included in the dairy cow's diet, as it improves the milk yield and quality (Mane et al. 2017), the performance of the offspring's as well as energy partitioned
${ }^{1}$ The Indonesian Beef Cattle Research Station, Grati-Pasuruan, East Java, Indonesia.

${ }^{2}$ Faculty of Veterinary Medicin, Bogor Agricultural University, West Java, Indonesia.

${ }^{3}$ The Indonesian Research Institute for Animal Production, CiawiBogor, West Java, Indonesia.

Corresponding Author: R. Antari. The Indonesian Beef Cattle Research Station, Grati-Pasuruan, East Java, Indonesia. Email: risa.antari@uq.net.au

How to cite this article: Antari, R., Mariyono, Anggraeny, Y.N., Krishna, N.H., Putri, A.S., Ulum, M.F. and Wina, E. (2022). Effect of Protected Calcium Salts of Fatty Acid-Amino Acid on Growth Rate of Young Ongole Crossbred Bulls. Indian Journal of Animal Research. DOI: 10.18805/IJAR.BF-1429.

Submitted: 18-08-2021 Accepted: 25-12-2021 Online: 14-02-2022

to body reserves of the cows (Marques et al. 2017; de Souza and Lock, 2018). A high-energy diet is expected to improve the nutritional content of crop residues and improves cattle productivity.

The information about the use of that supplement in beef cattle feed is scarce. Therefore, the current experiment aimed to test the efficacy of the supplement in the productive performance of young Ongole crossbred cattle.

\section{MATERIALS AND METHODS}

The following study was conducted under the guidelines of the Indonesian Code of Practice for the Care and Use of Animals for Scientific Purposes and was approved by the Indonesian Ministry of Agriculture Animal Ethics Committee (Balitbangtan/Lolitsapi/Rm/08/2020). 
The experiment was conducted in the Indonesian Beef Cattle Research Station (BCRS) at Grati, East Java, Indonesia from early November 2020 to mid of May 2021. It consisted of a 14-day pre-experimental period followed by a 190-day experimental period. Before the start of the experiment, 30 young Ongole crossbred bulls of approximately $350 \pm 14 \mathrm{~kg}(\mathrm{LW} \pm$ sem $), \pm 2$ years old were selected from the herd of the population in BCRS and were weighed and measured ( $L W$ and BCS), treated with anthelmintic. The bulls then were ranked and blocked on LW and housed in individual pens with one bull in each pen. Within each block, bulls were randomly allocated to each of the supplement treatments (Table 1). The experimental design was a randomized complete block design with three different supplement treatments and ten replicates.

All bulls were fed twice a day, at 07:00AM and 13:00AM with elephant grass (EG) Pennisetum purpureum containing $893 \mathrm{gOM}, 800 \mathrm{gCP}, 712 \mathrm{gNDF} / \mathrm{kg}$ DM and commercial concentrate (CONS containing $12 \%$ of crude protein, $5.3 \%$ of crude fat, $20 \%$ of crude fiber and $9 \%$ of ash), the feed was given at $4 \% \mathrm{LW}$ on a DM basis, with the ratio of $E G$ : CONS diet was 20:80.

The supplement was prepared by reaction of palm fatty acid distillate (PFAS) and calcium and lysine monohydro chloride was added and mixed thoroughly, the yellowish granules were then formed. The supplement was then dried at $60^{\circ} \mathrm{C}$ and grounded.

\section{Measurements}

The feed intake was measured daily by subtracting the amount of feed refused from the weight of feed offered. Subsamples of feed offered and refused were collected each day, bulked for a week mixed thoroughly and duplicate subsamples were collected for proximate analysis (DM, CP, organic matter (OM), crude fiber (CF) and total digestible nutrient (TDN) (AOAC, 2005).

Liveweight (LW) was measured early in the morning before feeding fortnightly. The body condition score (BCS) was assessed by the same person at the same time as weighing at the start and the end of the experiment, using a
1-5 scale. The blood samples were collected at the end of the experiment for analyses of plasma metabolites, plasma fat (triglyceride, LHL, HDL cholesterols) and glucose concentrations.

The fatdepth was measured at the end of the study. The parameters were backfat thickness (BF), longissimus dorsi thickness (LD), rump fat thickness (RF) and rump thickness (RT). Carcass quality characteristics were estimated using an ultrasound linear transducer at frequency 4.5 to $6.5 \mathrm{MHz}$ and a depth of $11 \mathrm{~cm}$. Application of ultrasound on BF and LD MS and PIF followed Ulum et al. (2014), while the measurement of the thickness of rump and rump fat according to Silva et al. (2012) performed between tuber coxae and tuber ischii.

\section{Statistical analysis}

The SPSS software program (SPSS Statistic, IBM, New York) version 23 with the General Linear Model was used to analyse animal measurement data. The data presented in the bar chart were least-square means. The $5 \%$ level significance was used to consider the difference between means.

\section{RESULTS AND DISCUSSION}

Intakes, liveweight gain, hip height gain and body condition score

Feed intake, liveweight gain, body confirmation and body condition score data are presented in Table 2. There was no significant difference in feed intake among treatment groups ( $P>0.05$; Table 2). All bulls ate around $11 \mathrm{~kg} / \mathrm{d}$ on a DM basis, equal to around $2.8 \% \mathrm{LW}$. Our results were above the maintenance level, 2.3\% LW (Syahniar et al. 2012). The results demonstrated that the production could be improved in cattle fed concentrate diet and elephant grass, although the supplement did not affect the DM intake across all the treatment groups as they were offered the same cons: EG ratio.

At the start, the liveweight of bulls was not different between treatments $(P>0.05)$. Bulls offered supplement at $0.6 \mathrm{~g} / \mathrm{kg} \mathrm{LW}$ were heavier and gained more LWG $(P<0.05$;

Table 1: Experimental design.

\begin{tabular}{lcl}
\hline Treatments & Number of bulls & Feeding \\
\hline A & 10 & Elephant grass + Concentrate diet (Control) \\
B & 10 & Control + supplement at $0.3 \mathrm{~g} / \mathrm{kg}$ liveweight \\
C & 10 & Control + supplement at $0.6 \mathrm{~g} / \mathrm{kg}$ liveweight \\
\hline
\end{tabular}

Table 2: Dry matter intake, liveweight gain, body condition score and the feed conversion ratio of Ongole crossbred bulls offered protected calcium salts of fatty acid-amino acid at nill (A), $0.3 \mathrm{~g} / \mathrm{kg} \mathrm{LW} \mathrm{(B)} \mathrm{and} 0.6 \mathrm{~g} / \mathrm{kg} \mathrm{LW} \mathrm{(C).}$

\begin{tabular}{lcccc}
\hline Parameter & A & B & C & P \\
\hline Dry matter intake (kg/day) & 11.4 & 11.9 & 11.7 & 0.71 \\
Liveweight gain (kg/d) & $0.64^{\mathrm{b}}$ & $0.78^{\mathrm{ab}}$ & $0.84^{\mathrm{a}}$ & 0.04 \\
Final liveweight & $480.4^{\mathrm{b}}$ & $499.5^{\mathrm{a}}$ & $503.4^{\mathrm{a}}$ & 0.03 \\
Body condition score* & 3 & 3 & 3 & 0.71 \\
Hip height gain (mm/100 day) & 56.0 & 69.2 & 77.5 & 0.19 \\
Feed conversion ratio (kg DM/kg LWG) & 17.7 & 15.9 & 14.8 & 0.38 \\
\hline
\end{tabular}

*at the end of the study. 
Table 2). The inclusion of $0.3 \mathrm{~g} / \mathrm{kg} \mathrm{LW}$ of supplement in the diet only improved slightly higher LWG, it indicated that the dose of the supplement that should be provided in the diet was $0.6 \mathrm{~g} / \mathrm{kg} \mathrm{LW}$. Our result was in line with He et al. (2018) who reported that the supplement increased LWG but did not affect DM intake. Studies showed varied results, the supplement increased the DM intake (da Cruz et al. 2019) while others showed a decreasing trend in DM intake (Fiorentini et al. 2014; de Souza et al. 2017). Those varieties of responses depend very much on the basal diet offered to the cattle and the level of which supplement was provided in the diet.

At the end, the BCS was not different between treatments. All groups reached BCS 3 , indicating they were all in good condition. The BCS change of those groups was $0.12 ; 0.08$ and 0.13 . Our results were in agreement with de Souza et al. (2017) who showed that the BCS was not affected by the supplement treatments. The BCS of cattle indicates a good index of subcutaneous fat, such as rump fat thickness although the LW showed a low correlation with both BCS and rump fat thickness (Ayres et al. 2009; Paul et al., 2020).

The hip height gain was not different between treatments $(\mathrm{P}=0.19$; Table 2). The $\mathrm{HH}$ gain was slightly lower than that was reported by Antari, (2018) in Brahman-cross steers at the same age $(85 \mathrm{~mm} / 100 \mathrm{~d})$. Our results showed that the bulls still grew taller but at a slower rate than the previous study, the differences were probably because of the nutritional content of the diet offered to the cattle and the breed.
The supplement included in the diet was related to an increase in FCR, although it was not a significant difference $(P>0.05)$ between each level of supplement. At the highest level of supplement, the bulls required less feed/kg LWG. Our results were within the range reported in the previous studies in Ongole crossbred bulls offered cassava tuber and Gliricidia $s p$., the FCR was $18 \mathrm{~kg}$ feed DM/kg LWG (Marsetyo et al. 2021) and in Ongole crossbred bulls fed elephant grass adlibitum, the FCR was $24 \mathrm{~kg}$ feed DM/kg LWG (Antari et al. 2016).

\section{Plasma glucose and fats}

The results showed that glucose, total cholesterol, triglyceride, LDL and HDL did not differ significantly ( $P>0.05$; Table 3). Our results were in contrast to a study in Holstein's calves fed the same supplement showed significant increasees in triglyceride, cholesterol and LDL concentrations and no supplement effect on glucose concentration was detected (Ngu et al., 2020). The variety of the results is probably because of the basal diet and the physiological status of the cattle differences.

\section{The fat depth and muscle depth}

The depths of backfat and muscle depth were presented in Table 4. There were no differences between treatments in all muscle depth affected by the supplement treatments $(P>0.05$; Table 4). The muscle depths in our study were larger than those in Bali cattle, around $53.9 \mathrm{~mm}$ at the same age at position $12-13^{\text {th }}$ (Jakaria et al. 2017), but lower than

Tabel 3. Plasma glucose, triglyceride, low-density lipoprotein (LDL), high-density lipoprotein (HDL) of Ongole crossbred bulls offered supplements containing protected calcium salts of fatty acid-amino acid at null (A), $0.3 \mathrm{~g} / \mathrm{kg} \mathrm{LW}$ (B) and $0.6 \mathrm{~g} / \mathrm{kg} \mathrm{LW}$.

\begin{tabular}{lccccc}
\hline Parameters & Stage & A & B & C & P \\
\hline Glucose $(\mathrm{mg} / \mathrm{dL})$ & Start & 29.4 & 29.9 & 30.3 & 0.50 \\
& End & 28.0 & 26.5 & 30.8 & 0.35 \\
Total cholesterol $(\mathrm{mg} / \mathrm{dL})$ & Start & 155.6 & 157.3 & 164.7 & 0.90 \\
& End & 241.6 & 214.1 & 262.5 & 0.45 \\
Triglyceride $(\mathrm{mg} / \mathrm{dL})$ & Start & 19.5 & 16.6 & 18.4 & 0.36 \\
& End & 19.8 & 16.2 & 17.5 & 0.37 \\
LDL $(\mathrm{mg} / \mathrm{dL})$ & Start & 29.4 & 29.9 & 30.3 & 0.99 \\
& End & 28 & 26,5 & 30,8 & 0.75 \\
HDL (mg/dL) & Start & 86.3 & 84.4 & 97.1 & 0.48 \\
& End & 130.4 & 122.7 & 132.3 & 0.85 \\
\hline
\end{tabular}

Tabel 4: The fat depth and muscle depth at $P 8,12^{\text {th }}-13^{\text {th }}$ and rump of Ongole crossbred bulls offered supplements containing protected calcium salts of fatty acid-amino acid at null (A), $0.3 \mathrm{~g} / \mathrm{kg} \mathrm{LW} \mathrm{(B)} \mathrm{and} 0.6 \mathrm{~g} / \mathrm{kg} \mathrm{LW}$.

\begin{tabular}{|c|c|c|c|c|c|}
\hline \multirow[t]{2}{*}{ Areas } & \multicolumn{3}{|c|}{ Treatments } & \multirow[t]{2}{*}{ sem } & \multirow[t]{2}{*}{$\mathrm{P}$} \\
\hline & $A$ & $\mathrm{~B}$ & $\mathrm{C}$ & & \\
\hline \multicolumn{6}{|l|}{ Muscle depth } \\
\hline P8 (mm) & 67.5 & 71.2 & 68.6 & 0.46 & 0.71 \\
\hline $12^{\text {th }}$ and $13^{\text {th }}$ ribs $(\mathrm{mm})$ & 60.9 & 61.6 & 64.1 & 0.49 & 0.79 \\
\hline Rump (mm) & 67.3 & 70.3 & 74.1 & 0.53 & 0.45 \\
\hline \multicolumn{6}{|l|}{ Fat depth } \\
\hline P8 (mm) & 6.0 & 4.7 & 5.5 & 0.07 & 0.16 \\
\hline $12^{\text {th }}$ and $13^{\text {th }}$ ribs $(\mathrm{mm})$ & $4.7^{\mathrm{b}}$ & $5.0^{\mathrm{ab}}$ & $5.9^{a}$ & 0.06 & 0.05 \\
\hline Rump (mm) & 5.2 & 5.4 & 5.3 & 0.09 & 0.98 \\
\hline
\end{tabular}


in Brahman cross steers (Antari, 2018), the eye muscle areas was around $68 \mathrm{~cm}^{2}$, the discrepancy of the results probably because of breed differences and feed type offered to the cattle. Thus, the depth of the muscle was likely affected by the basal diet offered to the bulls. The growth rate is affected largely by feed types, intake and chemical composition of the feed. Accordingly, to achieve a fast growth rate, cattle required a high energy and protein intake (Antari, 2018). Our bulls were relatively young so that the growth and development still occurred. Although the depth of all muscle areas was not different, the bulls fed supplement diet tended to have a larger muscle than their cohorts.

The fat depth in P8 and rump areas was not affected by the supplement treatment but it affected the depth of the fat in positions $12-13^{\text {th }}(P=0.05$; Table 4$)$. Our results indicated that the fat diet offered to the bulls affected the fat deposition in the $12-13^{\text {th }}$ area, the value was larger than those in Ongole crossbred $(3.56 \mathrm{~mm})$ and Simmental $\mathrm{x}$ Ongole (4.32 mm) (Ngadiyono et al. 2014). Moreover, Himia et al. (2021) reported that fat deposition occurred when the muscle growth reached a maximum rate at around the mature weight, after that muscle growth declined and fat deposition started to increase. Meanwhile, the mature weight of cattle occurred at different ages. For example, Freetly et al. (2011) reported that there was a variety of mature age and weight in beef cattle, the mature age and weight of Brahman cross was 58 weeks and $343 \mathrm{~kg}$, while Antari (2018) reported that mature age and weight of Brahman cross steers fed high energy and protein diet was 64 weeks and $850 \mathrm{~kg}$. Thus, the fat depth might be vary depending on age, feed and whether the animals were castrated or not.

\section{CONCLUSION}

To conclude, $0.6 \mathrm{~g} / \mathrm{kg}$ live weight of calcium salts of fatty acid-amino acid supplementation improve the growth rate of young Ongole crossbred bulls.

\section{ACKNOWLEDGEMENT}

We thank the Indonesia Endowment Fund for Education, the Indonesian Ministry of Finance who funded the work presented here.

\section{Conflict of interest: None.}

\section{REFERENCES}

Antari, R., Ningrum, G.P., Pamungkas, D., Mayberry, D.E., Marsetyo, Poppi, D.P. (2016). Growth rates and feed conversion rate of Ongole, Limousin-Ongole and Brahman bulls fed elephant grass (Pennisetum purpureum). Livestock Research for Rural Development. 28(9).

Antari, Risa. (2018). Skeletal growth in response to the nutritional and hormonal manipulation. Thesis. Faculty of Science. University of Queensland Australia.

AOAC. (2005). Official Methods of Analysis of AOAC International.
Ayres, H., Ferreira, R.M., de Souza Torres-Júnior, J.R., Demétrio, C.G.B., de Lima, C.G., Baruselli, P.S. (2009). Validation of body condition score as a predictor of subcutaneous fat in Nelore (Bos indicus) cows. Livestock Science. 123(2-3): 175-179.

Carvalho, V.V., Paulino, M.F., Detmann, E., Chizzotti, M.L., Martins, L.S., Silva, A.G., Lopes, S.A., Moura, F.H. (2017). Effects of supplements containing different additives on nutritional and productive performance of beef cattle grazing tropical grass. Tropical Animal Health and Production. 49(5): 983-988.

da Cruz, W.F.G., Schoonmaker, J.P., de Resende, F.D., Siqueira, G.R., Rodrigues, L.M., Zamudio, G.D.R., Ladeira, M.M. (2019). Effects of maternal protein supplementation and inclusion of rumen-protected fat in the finishing diet on nutrient digestibility and expression of intestinal genes in Nellore steers. Animal Science Journal. 90(9): 1200-1211.

de Souza, J. and Lock, A.L. (2018). Short communication: Comparison of a palmitic acid-enriched triglyceride supplement and calcium salts of palm fatty acids supplement on production responses of dairy cows. Journal of Dairy Science. 101(4): 3110-3117.

de Souza, Jonas, Batistel, F., Santos, F.A.P. (2017). Effect of sources of calcium salts of fatty acids on production, nutrient digestibility, energy balance and carryover effects of early lactation grazing dairy cows. Journal of Dairy Science. 100(2): 1072-1085.

Fiorentini, G., Carvalho, I.P.C., Messana, J.D., Castagnino, P.S., Berndt, A., Canesin, R.C., Frighetto, R.T.S., Berchielli, T.T. (2014). Effect of lipid sources with different fatty acid profiles on the intake, performance and methane emissions of feedlot Nellore steers. Journal of Animal Science. 92(4): 1613-1620.

Freetly, H.C., Kuehn, L.A., Cundiff, L.V. (2011). Growth curves of crossbred cows sired by hereford, angus, belgian blue, brahman, boran and tuli bulls and the fraction of mature body weight and height at puberty. Journal of Animal Science. 89(8): 2373-2379.

Gekara, O.J., Prigge, E.C., Bryan, W.B., Schettini, M., Nestor, E.L., Townsend, E.C. (2001). Influence of pasture sward height and concentrate supplementation on intake, digestibility and grazing time of lactating beef cows. Journal of Animal Science. 79(3): 745-752.

He, Y., Niu, W., Qiu, Q., Xia, C., Shao, T., Wang, H., Cao, B. (2018). Effect of calcium salt of long-chain fatty acids and alfalfa supplementation on performance of Holstein bulls. Oncotarget. 9(3): 3029.

Himia, N., Wiyatana, M.F., Rahmat, D., Dudi, Rosidin, R.A., Hadi, D.N. (2021). Pengaruh mutasi pada gen leptin terhadap tebal lemak punggung dan skor kondisi tubuh pada sapi peranakan Ongole. Ziraaáh. 46(1): 112-118.

Indarto, A., Handojo, L.A., Shofinita, D., Saadi, M.R., Yulistia, D., Hasyyati, F.I. (2020). In-vivo Test of Calcium Soap from Palm Fatty Acid Distillate (PFAD) in Three Cow Farms. IOP Conference Series: Materials Science and Engineering: 742(1).

Jakaria, Khasanah, H., Priyanto, R., Baihaqi, M., Ulum, M.F. (2017). Prediction of meat quality in Bali cattle using ultrasound imaging. Journal of the Indonesian Tropical Animal Agriculture. 42(2): 59-65. 
Effect of Protected Calcium Salts of Fatty Acid-Amino Acid on Growth Rate of Young Ongole Crossbred Bulls

Leng, R.A. (1990). Factors Affecting the Utilization of 'Poor-Quality' Forages by Ruminants Particularly Under Tropical Conditions. Nutrition Research Reviews. 3(1): 277-303.

Mane, S.H., Mandakmale, S.D., Nimbalkar, C.A., Kankhare, D.H., Lokhande, A.T. (2017). Economics of feeding protected protein and protected fat on crossbred cattle. Indian Journal of Animal Research. 51(6): 1080-1085.

Marques, R.S., Cooke, R.F., Rodrigues, M.C., Brandão, A.P., Schubach, K.M., Lippolis, K.D., Moriel, P., Perry, G.A., Lock, A., Bohnert, D.W. (2017). Effects of supplementing calcium salts of polyunsaturated fatty acids to lategestating beef cows on performance and physiological responses of the offspring. Journal of Animal Science. 95(12): 5347-5357.

Marsetyo, Sulendre, I.W., Takdir, M., Harper, K.J., Poppi, D.P. (2021). Formulating diets based on whole cassava tuber (Manihot esculenta) and gliricidia (Gliricidia sepium) increased feed intake, liveweight gain and income over feed cost of Ongole and Bali bulls fed low quality forage in Central Sulawesi, Indonesia. Animal Production Science. 61(8): 761-769.

Mediksa, T., Bekele, D., Marsha, T., Abera, H. (2021). Evaluation of Formulated Concentrate Feeds on Feed Intake and Milk Yield of Lactating Upgraded Dairy Cows at Nekemte and ljaji Towns. 7(2): 22-28.

Ngadiyono, N., Soeparno, Setiyono, and Carvalho, M.C. (2014). Carcass Characteristics and Meat Quality of Ongole Grade Cattle and Simmental Ongole Crossbred Cattle. In: Sustainable Livestock Production in the Perspective of Food Security, Policy, Genetic Resources and Climate Change. [Subandriyo, Kusmartono, S. Krishna Agung, K. Edi, P. Agung, S. Akhmad, W. Komang G, D. Siti, I. Ismeth, Darmono, P. Atien, W. Peter, H. Jian Lin, T.H. Jih, and I. Zulkifli. (Eds.)]. Gadjah Mada University Press. (pp. 2299-2302).
Ngu, N.T., Nhan, N.T.H., van Hon, N., Hung, L.T., Nam, L.T., Loc, H.T., Anh, L.H. (2020). Impact of dietary supplementation of chromium, sodium nitrate or mineral mixture on growth performance and rumen microbes of Brahman crossbred cattle. Indian Journal of Animal Research. 54(4): 440-445.

Paul, A., Mondal, S., Kumar, S., Kumari, T. (2020). Body condition scoring in dairy cows-A conceptual and systematic review. Indian Journal of Animal Research. 54(8): 929-935.

Santana Fernandes, L., Difante, G.D.S., Costa, M.G., Emerenciano Neto, J.V., Medeiros de Araújo, I.M., Santos Dantas, J.L., Chaves Gurgel, A.L. (2020). Pasture structure and sheep performance supplemented on different tropical grasses in the dry season. Revista Mexicana de Ciencias Pecuarias. 11(1): 89-101.

Silva, S. da L., Tarouco, J.U., Ferraz, J.B.S., Gomes, R. da C., Leme, P.R., Navajas, E.A. (2012). Prediction of retail beef yield, trim fat and proportion of high-valued cuts in nellore cattle using ultrasound live measurements. Revista Brasileira de Zootecnia. 41(9): 2025-2031.

Strohmaier, G.K., Fredericksen, E.D., Luchini, N.D. (2003). Method for manufacturing fatty acid calcium salts from high glyceride content oils.

Syahniar, T.M., Antari, R., Pamungkas, D., Marsetyo, Mayberry, D.E., Poppi, D.P. (2012). The level of tree legumes required to meet the maintenance energy requirements of Ongole (Bos indicus) cows fed rice straw in Indonesia. Animal Production Science. 52(7): 641-646.

Ulum, M.F., Suprapto, E., Jakaria. (2014). Citra Ultrasonografi Otot Punggung (Longisumus dorsi) pada Sapi Bali. Proceeding Kivnas Pdhi XIII. Konverensi IImiah Veteriner Nasional ke-13 Perhimpunan Dokter Hewan Indonesia, Palembang, Indonesia, Nov. 23-26, 2014. P. 368-369.

Wina, E. and Susana, I.W.R. (2013). Manfaat lemak terproteksi untuk meningkatkan produksi dan reproduksi ternak ruminansia. J. Wartazoa. 23(4): 176-184. 